\begin{tabular}{|c|c|c|}
\hline Beitr. Ent. & Berlin & ISSN 0005-805X \\
\hline $48(1998) 2$ & S. 343-351 & 05.10 .1998 \\
\hline
\end{tabular}

\title{
Two new Palaearctic species and two new synonyms of Atrecus JACQUELIN DU VAL
}

\section{(Coleoptera: Staphylinidae, Xantholinimae)}

With 2 figure plates

\section{VOLKER ASSING}

\section{Summary}

Atrecus parvioculatus sp. n. and A. schuelkei sp. n. are described from northeastern Anatolia and from western Sichuan (China), respectively. The following synonymies are established: A. pilicornis (PAYKULL) = A. suturalis (MOTSCHULSKY), syn. $\mathrm{n}_{\text {. }}$ and $A$. affinis $(\mathrm{PAYKULL})=A$. affinis caucasicus (ROUBAL), syn. n. A lectotype is designated for Othius suturalis MoTsCHULSKY, 1845. The primary and secondary sexual characters of the new taxa are illustrated, and a key to the eight Palaearctic species of the genus is presented.

\section{Key words}

Coleoptera - Staphylinidae - Xantholininae - Othiini - Atrecus - Palaearctic - China - Anatolia - taxonomy revision - new species - new synonyms - lectotype designation - key to species

\section{Zusammenfassung}

Zwei neue Arten der Gattung Atrecus werden beschrieben: Atrecus parvioculatus sp. n. aus Nordostanatolien und A. schuelkei sp. n. aus dem westlichen Sichuan (China). Zwei Taxa werden neu synonymisiert: A. pilicornis (PAYKULL) $=$ A. suturalis $($ MOTSCHULSKY), syn. n., und $A$. affinis (PAYKULL) $=A$. affinis caucasicus (ROUBAL), syn. n. Für Othius suturalis MOTSCHULSKY, 1845 wird ein Lektotypus designiert. Die primären und sekundären Sexualmerkmale der neuen Arten werden abgebildet, und für die acht paläarktischen Arten der Gattung wird eine Bestimmungstabelle vorgelegt.

\section{Introduction}

The Holarctic genus Atrecus JACQUELIN DU VAL currently comprises 12 species (with two subspecies), five of them known from the Western Palaearctic, one from Mongolia, one from Kamchatka, and five species from the Nearctic region (BERNHAUER \& SCHUBERT, 1914; BORDONI, 1987; CICERONI, 1990; COIFFAIT, 1972; SMETANA, 1967, 1982). Recent diagnoses including illustrations at least of the aedeagus - except for the hypogean and endemic A. casalei BORDONI, whose description is based on a single female - are available for all of the species with one exception: A. suturalis (MOTSCHULSKY, 1845), whose identity required clarification (SMETANA, 1967). 
An examination of recently collected material of Atrecus not only yielded a series of specimens, which proved to be conspecific with the probably singular syntype of $A$. suturalis, but also two new Palaearctic species, which are described below.

\section{Material and acknowledgements}

Type and further material from the following institutions and private collections was examined:

MHNG Muséum d'Histoire Naturelle, Genève (I. LÖBL)

ZMMU Zoological Museum, Moscow University (N. B. NIKITSKY)

cAss author's private collection

cKor Private collection H. Korge, Berlin

cPüt Private collection A. PüTZ, Eisenhüttenstadt

cSch Private collection M. SCHÜLKE, Berlin

cSme Private collection A. Smetana, Ottawa

I am indebted to the colleagues who kindly arranged the loan of types and further material. In addition, I would like to express my sincere thanks to MICHAEL SCHÜLKE for his cooperation and the gift of the holotype of $A$. schuelkei sp. n., and to ALEXEY SolodovNIKov, St.-Petersburg, for arranging a loan of the type of Atrecus suturalis (MOTSCHULSKY) and for his efforts and valuable comments regarding Atrecus affinis caucasicus.

\section{Measurements}

The measurements in the descriptions are indicated in $\mathrm{mm}$ and abbreviated as follows:

HW: $\quad$ maximal head width including eyes

HL: $\quad$ head length from front margin of clypeus to neck

PW: $\quad$ maximal width of pronotum

PL: $\quad$ length of pronotum along median line

EL: $\quad$ length of elytra from apex of scutellum to elytral hind margin

TiL: length of metatibiae (external aspect, from knee to insertion of first metatarsomere)

TaL: $\quad$ length of metatarsi (claws not included)

TL: $\quad$ total length from apex of mandibles to hind margin of tergum VIII.

\section{Atrecus suturalis (MOTSCHULSKY, 1845)}

Othius suturalis MOTSCHULSKY, 1845: 359f

\section{Type examined}

Lectotype $\widehat{\partial}$ [severely damaged, abdominal segments VIII and following missing], here designated: Othius suturalis m., Kamtsch., Typus/ Lectotypus ơ, Othius suturalis Motschulsky, desig. V. Assing 1998 (ZMMU).

\section{Additional material examined}

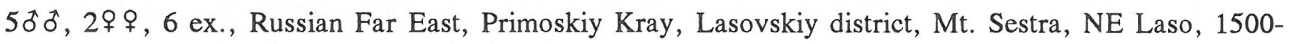
1600m, 7.-11.IX.1994, leg. Sundukov (cPüt, cSch, cAss).

According to MotschulsKy (1845), A. suturalis is distinguished from A. pilicornis (PAYKULL) by the broader and slightly smaller body. However, no constant external differences were observed between the specimen here designated as lectotype as well as additional material from the 
Russian Far East on the one hand, and central European A. pilicornis on the other hand. The same applies to the primary and secondary sexual characters. Therefore, the following synonymy is here established: Atrecus pilicornis (PAYKULL) = Othius suturalis MOTSCHULSKY, 1845, syn. $n$.

\section{Atrecus affinis caucasicus (ROUBAL, 1933)}

Baptolinus affinis caucasicus RoUBAL, 1933: 77

Roubal (1933) described the subspecies caucasicus from the Western Caucasus (Krasnaja Poljana), distinguishing it from $A$. affinis affinis only by the absence of the pair of frontal punctures on the head. In order to clarify the systematic and taxonomic status of the subspecies, material from the Caucasus (15 ex.: Abkhazia, Avadchara; 3 ex.: Caucasus minor, Trialetskiy Chrebet), northeastern Anatolia, Southern (Greece, Bulgaria) and Central Europe was examined. Considerable intraspecific, but apparently non-clinal variation was observed regarding several external characters: size, coloration, punctation, and microsculpture. One specimen from the Caucasus even had a pronotal punctation pattern similar to that in $A$. ardeanus CICERONI, with a pair of additional dorsal punctures on the pronotum. The single character distinguishing the two subspecies proved to be highly variable, too, and consequently of little taxonomic value: Of the 15 specimens collected in Abkhasia the frontal punctures were absent in eleven specimens, reduced to one puncture in one, minute in one, and distinct in two specimens. In two of the three specimens from Trialetskiy Chrebet, the punctures were present, and in the third specimen they were absent. A. SolodovniKov, St.-Petersburg, kindly examined the material in his private collection and in the Zoological Institute, St.-Petersburg, and found that of a total of 44 specimens collected in the northwestern Caucasus (almost all localities situated west of the Laba river and northwest of the Bzyb river) the frontal punctures were fully developed in four specimens, absent in 34 specimens, and the remaining six specimens represented intermediate character states (only traces of punctures or only a single puncture visible); in three specimens from Dagestan the punctures were absent (SOLODOVNIKOV, pers. comm.). One examined $q$ from NE Anatolia (Trabzon province) had distinct frontal punctures. According to KORGE (pers. comm.), two out of a total of ca. 25 specimens from northeastern Anatolia in his collection lacked the frontal punctures, some were transitional and the remainder possessed distinct frontal punctures; one of the two specimens without punctures was collected together with three specimens with well-developed punctures. In material from Central and Southern Europe, the size and depth of these punctures were subject to considerable intraspecific variation; in one specimen from Greece the punctures were minute. Finally, an examination of the otprimary and secondary sexual characters showed that the latter may be very variable - especially the chaetotaxy of the parameres (with two or three apical setae), and the shape and chaetotaxy of sternum IX (with the hind margin truncate to strongly concave) -, but yielded constant differences neither between specimens from the Caucasus and from other regions nor between specimens with and without the pair of frontal punctures. These observations are confirmed by SOLODOVNIKOV (pers. comm.), who examined the genitalia and external characters of his material. In view of the lack of constant differences in external morphology and sexual characters, the apparently increasing frequency of $A$. affinis without frontal punctures from northeastern Anatolia to the NW Caucasus is here regarded as an expression of clinal variation rather than evidence for the existence of two distinct subspecies. Remarkable clinal variation is also observed in other species of Othiini, e. g. in Othius lapidicola MÄRKEL \& KIESENWETTER (Assing, 1997). Consequently, the following synonymy is established: A. affinis (PAYKULL) = A. affinis caucasicus (ROUBAL), syn. n. 


\section{Atrecus parvioculatus sp. $\mathrm{n}$.}

Figs 1 a - e

Holotype ơ: 8.7.1976 - S. Vit, Ayder (m. 1400), Vallée de la Firtina, Rize, TURQUIE, litière de Rhododendrons (MHNG).

Paratypes: $2 q+$, same data as holotype (MHNG, cAss); $1 \delta^{\hat{\prime}}$, Anatolia bor., Korge \& Heinz leg./ Tal v. Ardesen (Ayder), 1000-1600m, 2.VIII.1965 (cKor).

\section{Diagnosis}

Measurements (range of specimens from "Firtina", specimen from "Ardesen"): HL: 0.79 $0.85,1.07$; HW: $0.76-0.83$, 1.07; PW: $0.65-0.71$. 0.88; PL: 0.88 - 0.94, 1.16; EL: 0.54 $0.57,0.71$; TiL: $0.65-0.68,0.88$; TaL: $0.41-0.50,0.51$; TL: $5.0-6.0,6.9$.

Colour of whole body \pm uniformly light to reddish brown.

Head slightly longer than wide, HL/HW: 1.00 - 1.04, distinctly wider than pronotum, HW/PW: 1.15 - 1.22; eyes reduced and minute, composed of only few ommatidia and without pigmentation; temples behind eyes \pm subparallel or slightly tapering in dorsal view; dorsal surface with distinct microsculpture, posteriorly predominantly composed of \pm diagonal or transverse striae, and anteriorly mixed with shorter meshes; posterior lateral area on both sides with numerous (ca. 12 - 20) punctures visible in dorsal view; frons with pair of shallow and ill-defined impressions anterior to frontal punctures.
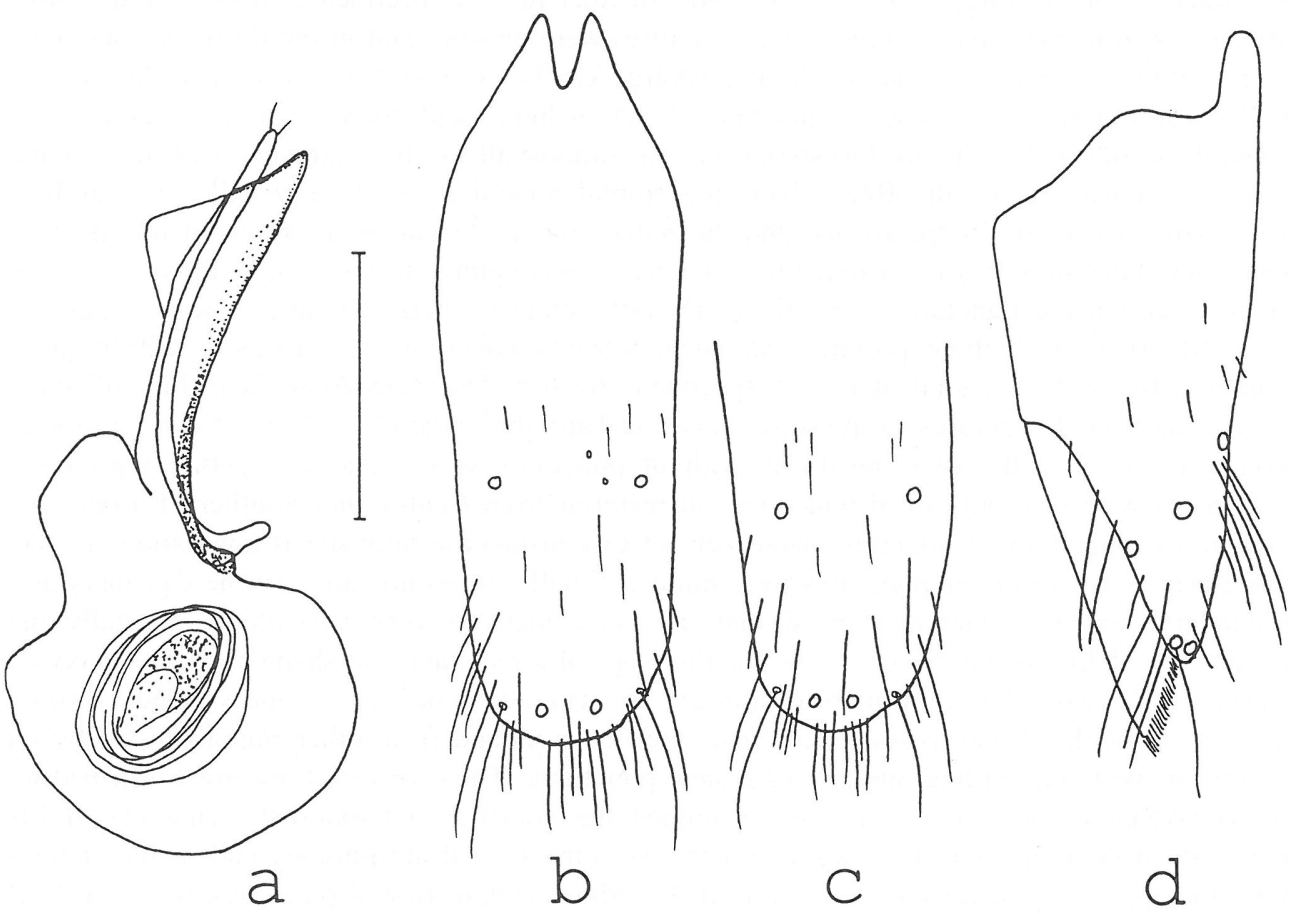

Fig. 1: A. parvioculatus sp. n.: aedeagus in lateral view (a); $\delta$ sternum IX of PT (b) and HT (c); $\delta$ lateral tergal sclerite IX and tergum $\mathrm{X}$ in lateral view (d); $\uparrow$ terminalia (e); setae partly omitted in b - e. Scales: $0.25 \mathrm{~mm}$. 
Pronotum slender and with \pm parallel or anteriorly weakly diverging lateral margins in dorsal view, 1.32 - $1.35 \mathrm{x}$ longer than wide; dorsal surface with transverse microsculpture; punctation similar to other Western Palaearctic congeners.

Elytra short (EL/PL: 0.60 - 0.62); punctures distinct, but of variable depth and size, and irregularly spaced; dorsal surface \pm uneven; microsculpture absent or indistinct; hind wings reduced; scutellum with weak, \pm transverse microsculpture, but without punctation; TiL/TaL: $1.3-1.7$.

Abdomen with sparse and minute punctation; microsculpture transverse, fine and shallow; palisade fringe on hind margin of tergum VII absent.

$\delta$ : protarsi moderately dilated; sternum VII with hind margin broadly and shallowly concave; hind margin of sternum VIII \pm truncate or weakly convex; hind margin of sternum IX \pm distinctly convex, hind angles not indicated (Figs 1b, c); lateral tergal sclerites IX slender, but not reaching hind margin of tergum X (Fig. 1d); parameres projecting over apex of median lobe, apically with two setae; flagellum with ca. $7-8$ coils (Fig. 1a).

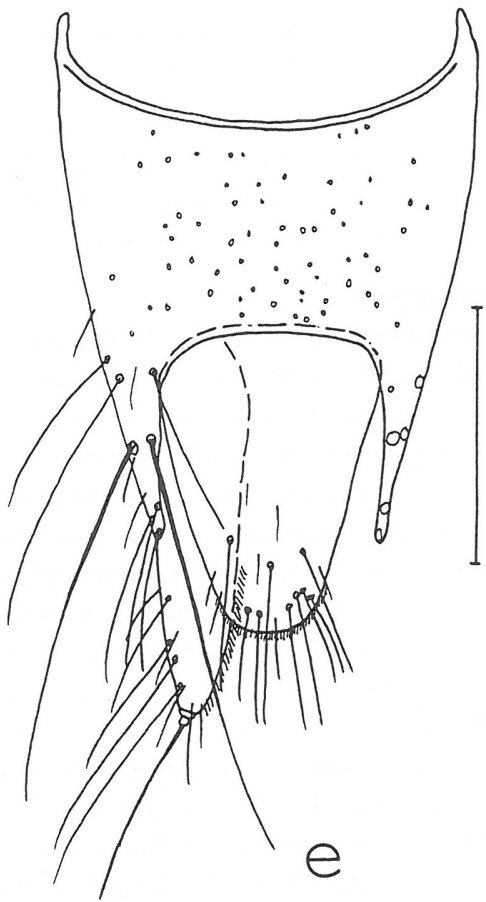

\$: protarsi slightly less dilated than in $\delta$; hind margin of sternum VIII weakly convex; hind margin of tergum $\mathrm{X}$ broadly convex, posterior setae long and unmodified; lateral tergal sclerites IX dorsally not separated and without anterior incision (Fig. 1e).

Derivatio nominis: The name (lat.: small-eyed) refers to a character separating this species from all congeners except for Atrecus casalei (BORDONI).

Comments and comparative notes: The $\delta$ paratype was distinctly larger than the remainder of the type specimens (see measurements) and had a somewhat more massive, posteriorly weakly dilated head. Additional distinguishing characters, however, were found neither in external morphology (including the $\delta$ secondary sexual characters) nor in the shape and internal structures of the aedeagus. Furthermore, the two localities, where these specimens were taken, are situated on the same mountain. The difference in size, therefore, indicates pronounced intraspecific variation, and the specimens from both localities are here treated as representatives of one and the same species.

From the only further microphthalmous congener, Atrecus casalei from eastern Greece, only the $q$ holotype of which has become known, A. parvioculatus is distinguished by the more slender and posteriorly not distinctly dilated head and by the much narrower and more slender pronotum.

Distribution and bionomics: The species has become known only from the Zigam dag south of Ardeşen in northeastern Anatolia; the $\delta$ paratype was collected on the southwestern and the remaining specimens on the northern slope. Judging from the reduced eyes and wings, the species is probably endemic to the area. The specimens from the northern slope ("Firtina") were collected in litter of Rhododendron, the $\delta$ paratype ("Tal von Ardesen") under a stone at ca. $1000 \mathrm{~m}$ (KORGE, pers. comm.). 


\section{Atrecus schuelkei sp. n.}

Figs $2 \mathrm{a}-\mathrm{c}$

Holotype ?: CHINA: W-Sichuan (13), Daxue Shan, Hailuogou Glacier Park, Camp 1, 2100m, 29.36.00N, 102.03.35E, 27.-31.05.1997, M. Schülke/ Sammlung M. Schülke Berlin (cAss). Paratype: 10 [teneral]: China, S Sichuan, S Xichang, Mt. Luoji, 2300-2500, litter, 16.24.07.96, Kurbatov (MHNG).

\section{Diagnosis}

Measurements (HT, PT): HL: 0.89, 0.88; HW: 0.95, 0.88; PW: 0.89, 0.85; PL: 1.04, 1.01; EL: 0.88, 0.80; TiL: 0.76, 0.76; TaL: 0.45, 0.47; TL: 6.5, 6.0.

Coloration of body, size and proportions similar to A. pilicornis (PAYKULL).

Head transverse or subquadrate, HL/HW: $0.94-1.00$, slightly wider than pronotum, HW/PW: 1.04 - 1.07; eyes fully developed; temples behind eyes subparallel in dorsal view; dorsal surface with less shine than in other Palaearctic species, due to characteristic very dense microsculpture, which posteriorly is predominantly composed of a mixture of transverse striae and meshes of variable length, and anteriorly of distinctly isodiametric meshes; posterior lateral area on both sides with ca. 14 - 20 punctures visible in dorsal view; frontal and ocular punctures as in $A$. pilicornis; frons with very shallow and ill-defined impressions anterior to frontal punctures.

Pronotum 1.17 - 1.20x longer than wide, maximal width near anterior angles; dorsal surface with fine, but distinct transverse microsculpture; punctation similar to other Western Palaearctic congeners. (In the holotype a further puncture-like impression without seta is present a short distance behind each of the posterior discal punctures.)

Elytra $0.79-0.84 \mathrm{x}$ the length of pronotum; macropunctation \pm regularly spaced, distinct, but rather small; dorsal surface more even than in $A$. pilicornis; microsculpture characteristic: composed of very dense and regularly spaced micropunctation, which at lower magnifications may be mistaken for isodiametric microsculpture; hind wings fully developed; scutellum with shallow, \pm transverse microsculpture, but without punctation; TiL/TaL: $1.61-1.67$.

Abdomen with punctation of similar size and depth as in A. pilicornis, but - at least in the holotype - distinctly denser; microsculpture transverse, fine and shallow; palisade fringe on hind margin of tergum VII present.

$\delta$ : dilatation of protarsi weak; sternum VII unmodified; hind margin of sternum VIII weakly convex; posterior margin of sternum IX distinctly convex and weakly serrate (Fig. 2b); aedeagus with median lobe apically very acute, in this respect similar to $A$. affinis, but on the whole smaller, and ventral process in relation to basal bulbus longer and in lateral view more distinctly curved subapically than in that species; parameres apically with two long setae; flagellum with ca. 15 coils (Fig. 2a).

$\%$ : protarsi as weakly dilated as in $A$. pilicornis, sexual dimorphism not very pronounced; hind margin of sternum VIII distinctly convex; tergum $\mathrm{X}$ of similar shape as in A. pilicornis, but with fewer long setae; lateral tergal sclerites IX longer than in A. pilicornis (Fig. 2c).

Derivatio nominis: This species is dedicated to Michael Schülke, Berlin, who collected the holotype.

Comparative notes: From all the Palaearctic congeners, A. schuelkei is readily distinguished especially by the more distinctly microsculptured and consequently less shiny head, the characteristic micropunctation of the elytra and the $\delta$ primary and secondary sexual characters.

Distribution: The species is known only from Sichuan, China; the fully developed wings suggest a wider distribution. 

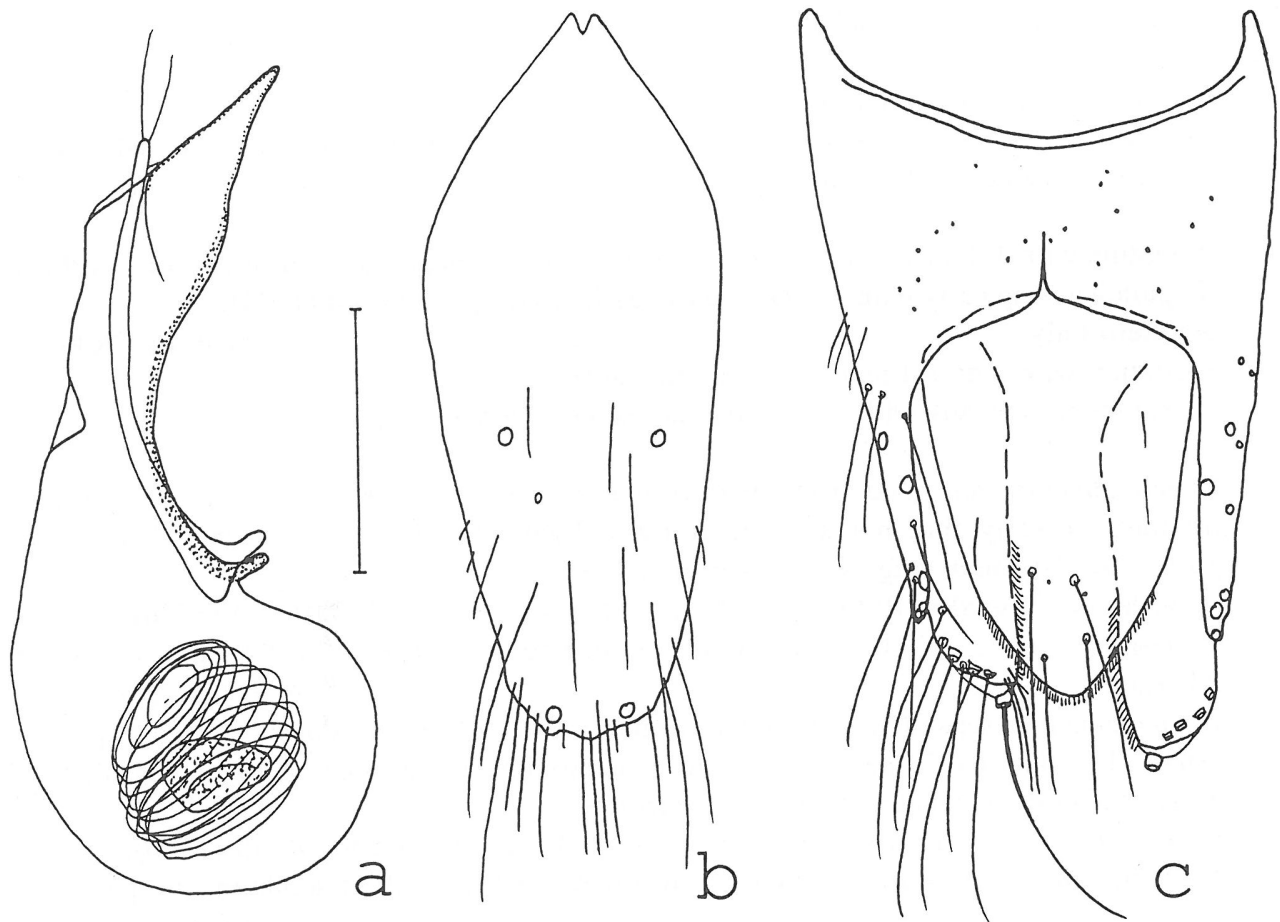

Fig. 2: A. schuelkei sp. n.: aedeagus in lateral view (a); $\delta$ sternum IX (b); $q$ terminalia (c); setae partly omitted in b - c. Scale: $0.25 \mathrm{~mm}$.

\section{Key to the Pallaearctic species of Atrecus JACQUELIN DU VAL}

The following key is based on examined material (including a $\delta$ paratype of $A$. brevicornis SMETANA from cSme), except for $A$. casalei (BORDONI) and $A$. ardeanus Ciceroni, for which detailed descriptions and illustrations are available.

1. Brachypterous hypogean species; eyes minute, composed of few ommatidia and without pigmentation; body colour uniformly light to reddish brown; size smaller . . . . . . . 2

- Macropterous and larger, mainly corticolous species with fully developed eyes composed of numerous ommatidia; at least head, pronotum and most of abdomen dark brown to

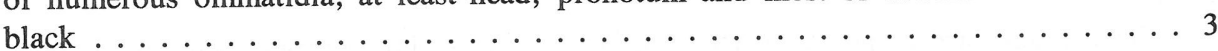

2. Head slightly longer than wide, posteriorly not or only indistinctly widened; pronotum much narrower than head and very slender, ca. 1.35x longer than wide.

$\delta$ : primary and secondary sexual characters as in Figs 1 a - d.

$\%$ : terminalia as in Fig. 1e.

Northeastern Anatolia ................... parvioculatus sp. $\mathrm{n}$. Head slightly transverse and posteriorly widened; pronotum only slightly narrower than head and less slender.

o: : unknown.

Eastern Greece

A. casalei (BORDONI) 
3. Posterolateral areas of head on each side with $<10$, usually $2-8$ punctures visible in dorsal view.

Western Palaearctic or Palaearctic species . . . . . . . . . . . . . . . . . 4

- Posterolateral areas of head with $>10$, usually 12 - 20 punctures visible in dorsal view.

Eastern Palaearctic or Palaearctic species . . . . . . . . . . . . . 6

4. Pronotum with 3 dorsal punctures on either side of midline; coloration similar to A. affinis. $\delta$ : parameres apically with 4 setae; aedeagus figured by CICERONI (1990).

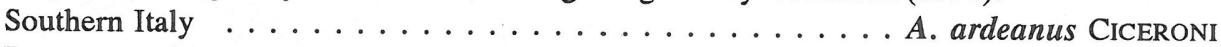

- Pronotum with 2 dorsal punctures on either side.

$\delta$ : parameres apically with $2-3$ setae; aedeagus different $\ldots \ldots \ldots \ldots$

5. Ocular puncture separated from anteromedian margin of eye by more than its diameter; pronotum usually (but not always) at least slightly lighter in colour than head; head posterolaterally on average with fewer punctures.

ठ: aedeagus figured in BORDONI (1982), COIFFATT (1972), and SZUJECKI (1976).

Widespread in the Western Palaearctic; according to BORDONI (1982) also in eastern Siberia . . . . . . . . . . . . . . . . . . . A. affinis (PAYKULL)

- Ocular puncture separated from anteromedian margin of eye by distance rarely equal to, usually less than its diameter; pronotum of approximately the same colour as head; head posterolaterally on average with more punctures.

ठ: aedeagus figured in BORDONI (1982), COIFFAIT (1972), and SZUJECKI (1976).

Northern and central Europe, mountainous regions in the north of southern Europe ...

\section{A. longiceps (FAUVEL)}

6. Head with denser and more distinct microsculpture and therefore less shiny; area between and surrounding frontal punctures with isodiametric microsculpture; elytra with shallow, but dense and distinct micropunctation.

$\delta$ : hind margin of sternum VIII convex; sternum IX more slender posteriorly (Fig. 2b); apex of median lobe very acute in lateral view; parameres apically with 2 long setae (Fig. 2a).

$\%$ : terminalia as in Fig. 2c.

Western China (Sichuan) .

A. schuelkei sp. n.

- Head with less dense microsculpture and more shine; area between and surrounding frontal punctures with transverse microsculpture; elytra without dense micropunctation.

$\delta$ : hind margin of sternum VIII usually weakly concave; sternum IX broader posteriorly; apex of median lobe distinctly less acute in lateral view; parameres apically with 3 setae 7

7. On average larger species; elytral surface \pm shiny, but rugosely sculptured, punctures therefore indistinct; antennae longer.

o: median lobe of aedeagus moderately bent in lateral view; aedeagus figured in BORDONI (1982), COIFFAIT (1972), and SZUJECKI (1976).

Palaearctic species, also indicated from Japan (NAOMI, 1989) . . A. pilicornis (PAYKULL)

- Smaller than average $A$. pilicornis; elytral surface smooth, very shiny, and with distinct punctures of variable in size and depth; antennae shorter.

ठ: median lobe of aedeagus strongly bent in lateral view (Fig. 6 in SMETANA, 1967).

Northern central Mongolia (Ulaanbaatar) . . . . . . . . A. brevicornis SMETANA 


\section{References}

AssING, V. 1997: A revision of Othius STEPHENS, 1829 (Coleoptera, Staphylinidae: Xantholininae). III. The species of the Western Palaearctic region exclusive of the Atlantic Islands. - Nova Suppl. Ent. Berlin 10: 3-130.

BernhAUER, M. \& SchuberT, K. 1914: Staphylinidae IV. - In: JUNK, W. \& S. SCHENKLING (eds.): Coleopterorum Catalogus, pars 57, Berlin: 289-408.

BordonI, A. 1982: Coleoptera Staphylinidae, Generalità - Xantholininae. - Fauna d'Italia 19: 1-434.

BordoNI, A. 1987: Baptolinus casalei n. sp. ipogea della Grecia (Col. Staphylinidae). - Boll. Mus. reg. Sci nat. Torino 5: 567-571.

CiCERoni, A. 1990: Una nuova specie di Atrecus dell'Italia meridionale (Coleoptera, Staphylinidae, Xantholininae). - Boll. Ass. Romana Entomol. 44(1989): 55-90.

CoIfFAIT, H. 1972: Coléoptères Staphylinidae de la région paléarctique occidentale. I. Généralités; sousfam. Xantholininae et Leptotyphlinae. - Nouv. Rev. Ent. Suppl. 2(2): 1-651.

MOTSCHULSKY, V. DE 1845: Observations sur le Musée Entomologique de l'Université Impériale de Moscou. - Bull. Soc. Imp. Nat. Moscou, 18 (Seconde Partie): 332-388.

NAOMI, S.-I. 1989: Staphylinidae. - In: A check list of Japanese insects, compiled by Y. HIRASHIMA, Kyushu University: 256-287.

RoubAL, J. 1933: Beschreibungen einiger Coleopteren-Neuheiten. - Entomol. Nachr.bl. 7: 77-78.

SMETANA, A. 1967: Ergebnisse der zoologischen Forschungen von Dr. Z. KASZAB in der Mongolei. 86. Staphylinidae II. Unterfamilien Paederinae, Xantholininae und Staphylininae (Coleoptera). - Acta ent. bohemoslov. 64: 195-218.

SMETANA, A. 1982: Revision of the subfamily Xantholininae of America north of Mexico (Coleoptera: Staphylinidae). - Mem. Entomol. Soc. Canada, No. 120: 1-389.

SZUJECKI, A. 1976: Klucze do oznaczania owadów Polski. Część 19. Chrząszcze - Coleoptera. Zeszyt 24 d. Kusakowate - Staphylinidae, Wydlużaki - Xantholininae. - Polskie Towarzystwo Entomologiczne, Warszawa: $44 \mathrm{pp}$.

Author's address:

VOLKER ASSING

Gabelsbergerstraße 2

D-30163 Hannover

Germany

\section{Besprechungen}

MARIA Sibylla Merian 1647-1717 : Künstlerin und Naturforscherin; [Katalog zur Ausstellung "MARIA SibYlla MERIAN (1647-1717), Künstlerin und Naturforscherin zwischen Frankfurt und Surinam" des Historischen Museums Frankfurt am Main vom 18. Dezember - 1. März 1998] / hrsg. von KURT WETTENGL. - Ostfildern: Verl. Gerd Hatje, 1997. - 275 S.: zahlr. Farbabb. - 98.- DM

Zum 350. Geburtstag von MARIA SibYLla MERIAN veranstaltete das Historische Museum Frankfurt am Main in der Zeit vom 18. Dezember 1997 bis zum 28. Februar 1998 in seinen Räumen eine Ausstellung, die einen umfassenden Überblick über ihr gesamtes Schaffen gab. Unter dem Motto 'Maria Sibylla Merian - Künstlerin und Naturforscherin' versuchte die Ausstellung erfolgreich diesen beiden Seiten der einzigartigen Frau gerecht zu werden. Über 100 Aquarellmalereien, darunter 40 Bilder aus St. Petersburg, die zum ersten Male öffentlich gezeigt wurden, ihr Studienbuch und ihre äußerst seltenen handkolorierten 